\title{
PENGEMBANGAN INSTRUMEN TES UNTUK MENGUKUR KEMAMPUAN PEMECAHAN MASALAH MATEMATIKA SISWA
}

\section{DEVELOPMENT OF TEST INSTRUMENTS TO MEASURE STUDENTS' MATHEMATICAL PROBLEM SOLVING ABILITIES}

\author{
Andi Dian Angriani ${ }^{1}$, Nursalam ${ }^{2}$, Nurul Fuadah ${ }^{3}$, Baharuddin $^{4}$ \\ ${ }_{1,2,3,4}$ Fakultas Tarbiyah dan Keguruan UIN Alauddin Makassar \\ 1,2,3,4 Kampus II: Jalan H. M. Yasin Limpo Nomor 36 Samata-Gowa \\ E-mail: dian.angriani@uin-alauddin.ac.id ${ }^{1}$, nursalam_ftk@uin-alauddin.ac.id ${ }^{2}$, \\ nufaha12@gmail.com ${ }^{3}$, baharuddin.abbas@uin-alauddin.ac.id ${ }^{4}$
}

\begin{abstract}
Abstrak:
Penelitian ini bertujuan menghasilkan sebuah instrumen tes untuk mengukur kemampuan pemecahan masalah matematika dengan melihat prosedur pengembangan dan kualitas instumen tes pemecahan masalah matematika yang dikembangkan. Jenis penelitian yang digunakan adalah penelitian research and development $(R \& D)$ yaitu pengembangan instrumen tes untuk mengukur kemampuan pemecahan masalah matematika. Model pengembangan perangkat ini dikembangkan berdasarkan model Tessmer yaitu tipe formatif evaluation, yaitu: (1) tahap preliminary, (2) tahap self evaluation, (3) tahap prototyping (expert review, one to one, small group), dan (4) tahap field test. Subjek uji coba dalam penelitian ini adalah siswa kelas VIII MTsN 1 Model Makassar yang berjumlah 36 orang siswa. Berdasarkan hasil uji coba yang dilakukan, diperoleh bahwa: (1) instrumen tes pemecahan masalah matematika sudah dikatakan "valid" karena berdasarkan hasil CVR yaitu 1 dan memenuhi kriteria yaitu $\geq 0,99$ dan CVI yaitu 1 dengan kategori sangat sesuai atau berada pada kisaran 0,68-1,00 (2) instrumen tes pemecahan masalah matematika sudah dikatakan reliabel dengan nilai 0,732 dengan kategori tinggi, dan berada pada kisaran $0,60<\mathrm{r} 11<0,80$ (3) instrumen tes pemecahan masalah matematika memiliki tingkat kesukaran yang cukup baik yaitu $60 \%$ dari soal memiliki tingkat kesukaran yang baik kemudian rata-rata tingkat kesukaran yang diperoleh adalah 0,58 dengan kategori sedang yaitu berada pada kisaran 0,31-0,70 (4) instrumen tes pemecahan masalah matematika memiliki daya pembeda yang sudah baik $93,34 \%$ soal memenuhi kriteria daya pembedan dan rata-rata daya pembeda yang diperoleh adalah 0,35 dengan kategori cukup atau berada pada kisaran $\mathrm{Dp}>0,2$. Dengan demikian instrumen tes pemecahan matematika siswa memiliki kualitas yang baik.
\end{abstract}

Kata Kunci: Pengembangan Instrumen Tes, Pemecahan Masalah, Matematika

\begin{abstract}
Abstrak:
This study aims to produce a test instrument to measure the ability to solve mathematical problems by looking at the test instrument development procedures and the quality of the instuments of the mathematical problem solving test developed. The type of research used is research and development $(R \& D)$ research, namely the development of test instruments to measure the ability to solve mathematical problems. The development model of this device was developed based on Tessmer model that is formative evaluation type, namely: (1) preliminary stage, (2) self evaluation stage, (3) prototyping stage (expert review, one to one, small group), and (4) field test. The subjects of the experiment were VIII students of MTsN 1 Model Makassar which amounted to 36 students Based on the results of experiments conducted, it is found that: (1) math problem solving test instrument has been said "valid" because based on the CVR results are 1 and meet the criteria of $\geq 0.99$ and CVI is 1 with a category sesuait or in the range 0,68-1,00 (2) mathematical problem-solving test instrument is said to be reliable with a value of 0.732 with high category, and is in the range of $0.60<r 11<0.80$ (3) Instrument test The math problem
\end{abstract}


solving device has a level of difficulty good cuku that is $60 \%$ of the problem has a good level of difficulty then the average level of difficulty obtained is 0.58 with the medium category that is in the range of 0.31 to 0.70. (4) Instrument test Math problem solving device has power a good differentiator $93.34 \%$ of the question meets the criteria of the power of pembedan and the average distinguishing power obtained is 0.35 with sufficient category or is in the range $D p>0.2$. With demikina test instrument of mathematical solving students have good quality.

Keyword : Development of Test Instruments, Problem solving, Mathemathic

\section{Pendahuluan}

Kegiatan pembelajaran terdiri dari proses belajar dan mengajar. Belajar adalah kegiatan yang paling pokok dalam pendidikan, belajar merupakan proses perubahan baik dari tingkah laku maupun pengetahuan, perubahan yang dimaksud disini adalah perubahan yang mengarah kepada hal yang positif. Sedangkan mengajar adalah bimbingan kepada seseorang dalam proses belajar. Berhasil tidaknya pencapaian tujuan pendidikan banyak bergantung kepada proses pembelajaran yang dialami oleh siswa sebagai peserta didik. Oleh karena itu dalam mengukur suatu proses pembelajaran maka hasil belajar dari peserta didik perlu diketahui. Hasil belajar peserta didik dapat diketahui dengan mengadakan suatu evaluasi.

Menurut Mania (2014) evaluasi adalah suatu proses penilaian/tidakan yang dilakukan untuk mengetahui tingkat keberhasilan dari suatu program pendidikan, pengajaran ataupun pelatihan yang telah dilaksanakan. Hasil dari evaluasi tersebut dapat memberi motivasi bagi guru maupun siswa, agar mereka akan lebih giat belajar dan meningkatkan proses berfikirnya. Oleh karna itu dalam memperoleh hasil evaluasi maka dilakukan pengukuran dan penilaian.

Menurut Emori dalam Sugiyono (2014: 102), alat ukur dalam penelitian biasanya dinamakan instrumen penelitian. Instrumen adalah alat ukur dalam rangka pengumpulan data. Dalam ilmu sosial banyak ahli yang telah membakukan alat ukur atau instrumen untuk beberapa kebutuhan pengukuran. Dalam penelitian sosial bila hendak menggunakan alat ukur baku untuk pengukuran maka pengumpulan data perlu melaporkan hasil pengujian kualitas ukur oleh orang yang telah membakukannya (Purwanto, 2014: 6).

Instrumen penelitian memegang peranan penting dalam upaya mencapai tujuan penelitian. Bobot atau mutu penelitian kerapkali dinilai dari kualitas instrumen yang digunakan. Hal ini tidaklah mengherankan, karena instrumen penelitian adalah alat-alat yang digunakan untuk memperoleh atau mengumpulkan data dalam rangka memcahkan masalah penelitian atau menggapai tujuan penelitian. Jika data yang diperoleh tidak akurat (valid), maka keputusan yang diambilpun tidak tepat. Pembahasan instrumen penelitian dalam kaitan-kaitannya dengan bidang sosial dan pendidikan, diperlukan adanya pemilahan antara penelitian yang mengguanakan pendekatan kualitatif dengan menggunakan penelitian kuantitatif (Mustami, 2015: 99-100).

Pengumpulan informasi tentang proses belajar dapat diperoleh dengan melakukan pengukuran. Pengukuran dilakukan dengan menggunakan alat ukur atau instrumen. Pada umumnya dalam mengukur hasil belajar, guru dominan menggunakan instrumen berupa tes.

Tes merupakan cara penilaian yang dirancang dan dilaksanakan kepada peserta didik pada waktu dan tempat tertentu serta dalam kondisi yang memenuhi syarat-syarat 
tertentu yang jelas. Tes sebagai alat penilaian adalah pertanyaan-pertanyaan yang diberikan kepada siswa dalam bentuk tulisan (tes tulisan), atau dalam bentuk perbuatan (tes tindakan). Tes pada umumnya digunakan untuk menilai dan mengukur hasil belajar siswa, terutama hasil belajar kognitif berkenaan dengan penguasaan bahan pengajaran sesuai dengan tujuan pembelajaran (Nursalam, 2012: 121).

Sebuah tes yang dapat dikatakan baik sebagai alat pengukur, harus memenuhi persyaratan, yaitu memiliki validitas, reliabilitas, objektivitas, praktikabilitas dan ekonomis (Arikunto, 2010). Tujuan tes yang penting adalah untuk: 1) mengetahui tingkat kemampuan peserta didik, 2) mengukur pertumbuhan dan perkembangan peserta didik, 3) mendiagnosis kesulitan belajar peserta didik , 4) mengetahui hasil pengajaran, 5) mengetahui hasil belajar dan 6) mendorong pendidik mengajar yang lebih baik dan peserta didik belajar lebih baik (Mardapi, 2008). Dari tujuan tersebut menujukkan bahwa tes adalah salah satu hal penting yang perlu diperhatikan karena kualitas sebuah tes menetukan keakuratan dalam mengukur hasil belajar siswa atau peserta didik.

Matematika adalah salah satu bidang studi yang mengutamakan kemampuan ranah kognitif. Aspek atau domain kognitif adalah ranah yang mencakup kegiatan mental (otak). Menurut Bloom, segala upaya yang menyangkut otak adalah termasuk dalam ranah kognitif (Nursalam, 2012). Matematika merupakan mata pelajaran yang mencakup semua aspek dari ranah kognitif karena didalam mata pelajaran matematika itu sendiri peserta didik diharapkan mencapai tingkatan kemampuan tersebut. Mulai dari kemampuan mengingat, memahami, menerapkan, menganalisis sampai dengan kemampuan mensintesis.

Salah satu penilaian yang penting dalam mata pelajaran matematika adalah kemampuan pemecahan masalah. The National Council of Teacher of Mathematics (NCTM, 1989) menyatakan pentingnya pemecahan masalah pada kurikulum matematika Pendapat tersebut menjelaskan bahwa pemecahan masalah seharusnya menjadi fokus sentral dari kurikulum matematika. Dengan demikian kemampuan pemecahan masalah matematika sangat penting dan menjadi tujuan utama dalam pembelajaran matematika. Pemecahan masalah adalah sebuah proses yang harus diserap pada semua program dan menyediakan konteks di mana konsep, prinsip dan keterampilan dipelajari. Dengan pemecahan masalah matematika peserta didik dilatih untuk menguasai konsep dan prinsip dari suatu materi dan siswa dilatih untuk terampil dalam memcahkan soal matematika (Lahinda dan Jailani, 2015).

Berdasarkan tes PISA negara Indonesia masih berada pada urutan yang masih terbilang rendah. Hasil terbaru dari PISA 2015, ini menunjukkan bahwa masih rendahnya tingkat kemampuan siswa-siswa Indonesia jika dibandingkan dengan negara-negara lain. Berdasarkan hal tersebut semakin jelas bahwa kemampuan siswa Indonesia dalam menyelesaikan soal-soal yang menuntut kemampuan untuk menelaah, memberi alasan dan mengomunikasikannya secara efektif, serta memecahkan dan menginterpretasikan permasalahan dalam berbagai situasi masih sangat kurang. Berdasarkan hasil PISA, dari 76 negara peserta PISA 2015, Indonesia menempati posisi ke 69 untuk PISA Matematika dengan memperoleh skor 386 poin. Oleh karena itu perlu adanya usaha untuk meningkatkan prestasi Indonesia dalam bidang matematika, salah satunya dengan meningkatkan kemampuan pemecahan masalah matematika siswa.

Melalui pembelajaran pemecahan masalah matematika, siswa diharapkan memperoleh pengalaman dengan menggunakan pengetahuan serta ketrampilan yang 
telah dimiliki untuk diterapkan pada pemecahan masalah yang baru, menggunakan pengetahuan, keterampilan, dan pemahaman yang diperoleh sebelumnya memenuhi tuntutan situasi yang tidak biasa (Krulik dan Rudnik dalam Wahyuningrum 2014). Oleh karena itu, pembelajaran matematika itu sendiri tidak hanya diarahkan pada peningkatan kemampuan siswa dalam menyelesaikan soal-soal terkait perhitungan berupa angkaangka, tetapi juga diarahkan kepada peningkatan kemampuan siswa dalam pemecahan masalah yang secara kontekstual menggunakan matematika untuk memecahkannya. Soal pemecahana masalah matematika biasanya dalam bentuk soal uraian atau soal cerita. Masalah matematika dalam bentuk soal uraian lebih sulit dipecahkan oleh siswa dibandingkan dengan soal-soal yang hanya melibatkan bilangan-bilangan atau soal yang hanya terkait dengan perhitungan angka-angka.

Branca dalam (Rahayu dan kartono, 2012) mengemukakan bahwa pemecahan masalah adalah jantung matematika. Hal ini sesuai dengan NCTM (1989) menyatakan bahwa pemecahan masalah merupakan suatu kesatuan bagian dalam pembelajaran matematika, jadi seharusnya tidak terpisah dari pembelajaran matematika. Matematis pemecahan masalah adalah alat yang digunakan tidak hanya untuk membantu siswa kembangkan kemampuan berpikir, tapi juga membantu mereka untuk berkembang keterampilan dasar dalam memecahkan masalah, terutama dalam kehidupan sehari-hari. Menurut Syam dkk (2016) proses berpikir dalam pemecahan masalah merupakan hal penting yang perlu mendapat perhatian para pendidik terutama membantu siswa agra dapat mengembangkan kemampuannya memecahkan masalah.

Berdasarkan penjelasan diatas bahwa pemecahan masalah matematika sebagai suatu keterampilan dalam proses pembelajaran matematika, kemudian untuk mengukur suatu kemampuan pemecahan masalah matematika, dapat ditentukan dengan melihat stiap langkah yang digunakan dalam pemecahan masalah suatu soal, dengan menilai kemampuan memahami soal dengan mengidentifikasinya, merencanakan strategi penyelesaian soal kemudian menyelesaikan soal berdasarkan strategi yang telah direncanakan dan yang terakhir memeriksa kembali dengan memberikan penafsiran solusi atau kesimpulan.

Penyelesaian masalah pada soal uraian memiliki langkah-langkah dalam penyelesaiannya. Menurut Polya (1971) memaparkan bahwa solusi soal pemecahan masalah terbagai atas empat langkah penyelesaian, yaitu memahami masalah, membuat rencana pemecahan masalah, melaksanakan rencana pemecahan masalah dan memeriksa kembali semua lagkah yang telah dikerjakan. Jadi, untuk menyelesaikan soal uraian, terlebih dahulu dimulai dari memahami masalah dalam soal tersebut kemudian siswa merencanakan pemecahan masalah berdasarkan konsep dari materi yang berkenaan dengan soal tersebut setelah itu, siswa melaksanakan pemecahan masalah dan yang terakhir siswa memeriksa kembali langkah yang telah dikerjakan.

Disetiap sekolah pada umumnya masih dominan menggunakan soal-soal berbentuk pilihan ganda atau soal-soal yang langsung menggunakan rumus tanpa adanya proses analisis soal terlebih dahulu, sehingga soal tersebut kurang cocok untuk menilai kemampuan pemecahan masalah matematika pada siswa.

Tujuan terjadinya proses pemecahan masalah dalam kegiatan belajar diperlukan adanya soal-soal yang memenuhi kriteria soal pemecahan masalah. Sebagai pedoman penyusunan soal pemecahan masalah, Menurut Sovchik dalam Purnama (2014), soal pemecahan masalah adalah soal yang menuntut siswa untuk: (1) menggunakan beragam prosedur dimana para siswa dituntut untuk menemukan hubungan antara pengalaman sebelumnya dengan masalah yang diberikan untuk mendapatkan solusi, (2) melibatkan 
manipulasi atau operasi dari pengetahuan yang telah diketahui sebelumnya, (3) memahami konsep-konsep dan istilah-istilah matematika, (4) mencatat kesamaan, perbedaan dan perumpamaan, (5) mengidentifikasi hal-hal kritis dan memilih prosedur dan data yang benar, (6) mencatat perincian yang tidak relevan, (7) memvisualisasikan dan menginterpretasikan fakta-fakta yang kuantitatif atau fakta-fakta mengenai tempat dan hubungan antar fakta, (8) membuat generalisasi dari contoh-contoh yang diberikan, dan mengestimasi dan menganalisa.

Berdasarkan analisis soal buatan guru di MTsN 1 Model Makassar pada kelas VII. Soal yang digunakan pada umumnya soal yang langsung menggunakan rumus, kemudian berdasarkan kriteria pemecahan masalah matematika yang telah dibahas sebelumnya, maka soal tersebut kurang sesuai dengan kriteria soal untuk mengukur kemampuan pemecahan masalah matematika.

Berdasarkan hal tersebut pengembangan instrumen tes dalam mengukur kemampuan pemecahan masalah perlu dilakukan. Untuk mengukur kemampuan pemecahan masalah instrumen tes atau soal yang digunakan adalah soal uraian, agar dapat mengetahui sejauh mana siswa mendalami suatu masalah yang diteskan. Evy Yosita Silva, zulkardi dan Darmawijoyo berkolaborasi dalam mengembangkan instrumen tes dalam mengukur kemampuan pemecahan masalah. Judul penelitian yang mereka lakukan yaitu pengembangan soal matematika model PISA pada konten uncertainty untuk mengukur kemampuan pemecahan masalah matematika siswa sekolah menengah pertama. Peneliti tersebut mengahasilkan instrumen tes atau soal yang memiliki efek potential yang positif terhadap kemampuan pemecahan masalah matematika siswa.

Berdasarkan hal tersebut peneliti tertarik untuk mengadakan penelitian yang berjudul "Pengembangan Instrumen Tes Untuk Mengukur Kemampuan Pemecahan Masalah Matematika Siswa MTsN 1 Model Makassar".

\section{Metode Penelitian}

Jenis penelitian yang digunakan adalah penelitian Research \& Development $(\mathrm{R}$ \& D) atau penelitian pengembangan. Model pengembangan yang digunakan dalam penelitian ini adalah model pengembangan Tessmer yang dikenal dengan model pengembangan tipe formatif evaluation. Pengembangan Tessmer terdiri dari empat tahap yaitu preliminary, self evaluation, tahap prototyping (expert reviews, one-to-one dan small group) dan field test. Berikut merupakan prosedur pengembangan yang dilakukan.

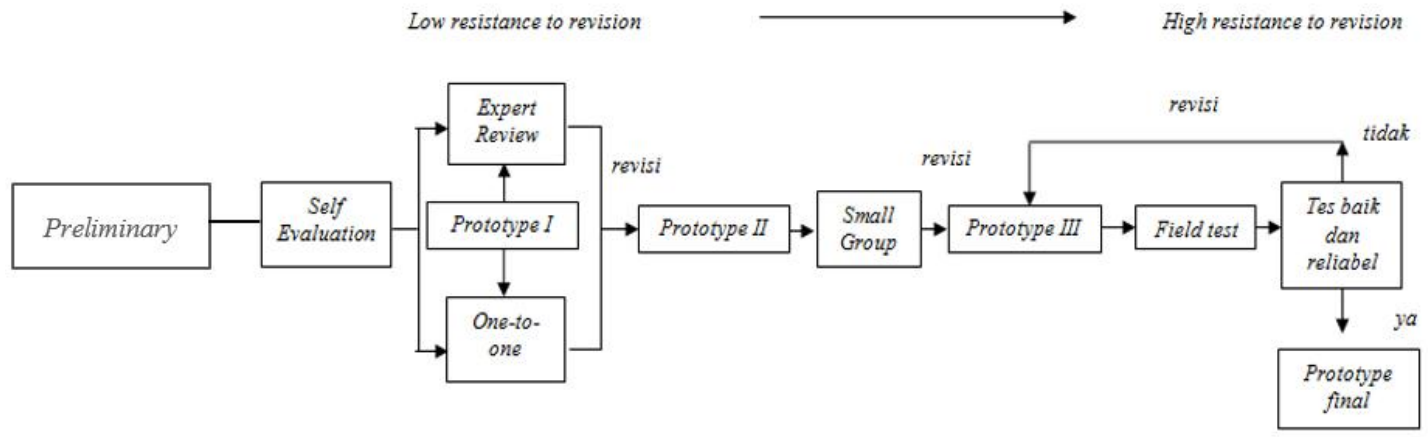

Gambar 1. Model tipe fromatife research Tessmer 
Subjek uji coba yang digunakan pada penelitian ini adalah siswa kelas VIII-3 MTsN 1 Model Makassar pada semester genap tahun ajaran 2016/2017. Teknik pengumpulan data terdiri dari tes, angket. Instrumen pengumpulan data berupa instrumen tes, lembar validasi dan angket. Teknik analisis data terdidiri dari validasi instrumen tes kemampuan pemecahan masalah, analisis angket respon siswa, uji reliabilitas tes kemampuan pemecahan masalah, analisis tingkat kesukaran instrumen tes kemampuan pemecahan masalah matematika, analisis daya pembeda instrumen tes kemampuan pemecahan masalah matematika dan analisis data hasil kemampuan pemecahan masalah matematika siswa.

\section{Hasil Penelitian dan Pembahasan}

\subsection{Hasil Penelitian}

Adapun hasil pengembangan dari penelitian ini, sebagai berikut:

\subsubsection{Hasil Pengembangan}

\section{Tahap Preliminary}

Tahapan ini dimulai dengan pengumpulan beberapa referensi yang berhubungan dengan penelitian ini, yakni tentang pengembangan instrumen tes untuk mengukur kemampuan pemecahan masalah matematika. selanjutnya dilakukan kegiatan penentuan tempat dan subjek uji coba penelitian. Tempat uji coba pada penelitian ini adalah MTsN 1 Model Makassar. Sedangkan subjek uji coba pada penelitian ini adalah siswa kelas VIII-3.

\section{Tahap Self Evaluation}

Tahap self evaluatin terdiri dari dua bagian yaitu tahap analisis dan tahap desain. Tahap analisis ini terdiri dari analisis kurikulum, analisis siswa dan analisis materi;

\section{- Analisis Kurikulum}

Berdasarkan wawancara dengan guru matematika MTsN 1 Model Makassar diketahui bahwa kurikulum 2013 sudah diterapkan pada saat mulai dicanangkannya kurikulum 2013.

\section{- Analisis Siwa}

Kegiatan analisis siswa difokuskan pada siswa kelas VIII sebagai subjek uji coba kaena siswa kelas VIII telah menerima materi. Jumlah siswa pada kelas tersebut adalah 40 orang siswa. Berdasarkan wawancara guru matematika dapat diketahui bahwa pengetahuan siswa kelas VIII-3 MTsN 1 Model Makassar Ada yang berkemampuan kurang, sedang, dan tinggi.

\section{- Analisis Materi}

Analisis materi merupakan kegiatan mengidentiifikasi konsep-konsep utama yang akan digunakan dalam membuat soal. Berdasarkan hal tersebut maka, materinya adalah perbandingan, aritmatikas sosial, garis dan sudut, segitiga dan segiempat dan penyajian data.

\section{Tahap Prototyping (Validasi, Evaluasi dan Revisi)}

\section{1) Expert Review}

Validasi instrumen dilakukan dengan cara memberikan lembar validasi instrumen kisi-kisi tes, soal tes, dan kunci jawaban tes, kepada validator. Yang terdiri atas dua dosen matematika Fakultas Tarbiyah dan Keguruan terdiri dari 
Validator 1 (expert 1) dan validator 2 (expert 2) dan satu guru matematika MTSN 1 Model Makassar yaitu Validator 3 (expert 3). Validator memberikan pendapat: prototipe dapat digunakan tanpa revisi, ada sebagian komponen soal yang perlu direvisi, atau semua komponen harus direvisi.

2) One to one

Selain soal instrumen tes pemecahan masalah matematika divalidasi oleh expert, soal tes tersebut juga diuji cobakan one to one pada beberapa siswa MTsN 1 Model Makassar. Siswa tersebut merupakan 3 siswa nonsubjek uji coba penelitian yang terdiri dari siswa yang berkemampuan rendah, siswa yang berkemampuan rendah sedang dan siswa yang berkemampuan rendah tinggi. Kemudian siswa tersebut dibagikan angket respon siswa untuk melihat keterbacaan soal-soal tersebut.

3) Small Group

Hasil revisi dan komentar dari expert review dan one to one dijadikan dasar untuk mendesain soal pada tahap selanjutnya yang menghasilkan prototype 2 dan diujicobakan pada small group non subjek penelitian yang terdiri dari 6 orang siswa. Terdiri dari 2 siswa berkemampuan tinggi, 2 siswa berkemampuan sedang dan 2 siswa berkemmpuan tinggi. Siswa diminta untuk mengerjakan soal pemecahan masalah dan setelah diminta untuk mengisi angket respon yang telah disediakan.

\section{Field Test}

Prototipe yang telah divalidasi dan direvisi (prototype 2), diujicobakan pada subjek uji coba penelitian yaitu siswa kelas VIII-3 MTsN 1 Model Makassar. Kelas tersebut terdi dari 40 orang siswa namun, pada saat uji coba beberapa siwa tidak masuk sekolah sehingga total siswa yang dijadikan subjek uji coba yaitu 36 orang siswa.

Siswa diminta untuk mengerjakan tes kemampuan pemecahan masalah matematika yang berisi 15 butir soal uraian. Pada awal kegiatan tes peneliti membagikan soal dan lembar jawaban kepada siswa.

\subsubsection{Hasil Pengembangan Instrumen Tes Pemecahan Masalah Matematika Validasi Instrumen Tes Pemecahan Masalah}

Proses judgment validasi isi instrumen tes untuk mengukur kemampuan pemecahan masalah matematika dilakukan oleh 3 expert (validator) diantaranya dua orang dosen program studi pendidikan matematika, dan satu orang guru mata pelajaran matemtika. Metode analisis validasi yang digunakan yaitu metode content Validaty Ratio (CVR) dan Content Validaty Index (CVI). Hasil dari analisis validasi yaitu sebagai berikut.

Tabel 1. Hasil Validitas CVR dan CVI setelah Revisi

\begin{tabular}{|c|c|c|c|c|c|c|}
\hline $\begin{array}{l}\text { Butir } \\
\text { Soal }\end{array}$ & $\begin{array}{c}\text { Expert } \\
1\end{array}$ & $\begin{array}{c}\text { Expert } \\
2\end{array}$ & $\begin{array}{c}\text { Expert } \\
3\end{array}$ & CVR & CVI & Keterangan \\
\hline 1 & 1 & 1 & 1 & 1 & \multirow{3}{*}{1} & Butir mendukung validitas isi tes \\
\hline 2 & 1 & 1 & 1 & 1 & & Butir mendukung validitas isi tes \\
\hline 3 & 1 & 1 & 1 & 1 & & Butir mendukung validitas isi tes \\
\hline
\end{tabular}




\begin{tabular}{|c|c|c|c|c|c|}
\hline 4 & 1 & 1 & 1 & 1 & Butir mendukung validitas isi tes \\
\hline 5 & 1 & 1 & 1 & 1 & Butir mendukung validitas isi tes \\
\hline 6 & 1 & 1 & 1 & 1 & Butir mendukung validitas isi tes \\
\hline 7 & 1 & 1 & 1 & 1 & Butir mendukung validitas isi tes \\
\hline 8 & 1 & 1 & 1 & 1 & Butir mendukung validitas isi tes \\
\hline 9 & 1 & 1 & 1 & 1 & Butir mendukung validitas isi tes \\
\hline 10 & 1 & 1 & 1 & 1 & Butir mendukung validitas isi tes \\
\hline 11 & 1 & 1 & 1 & 1 & Butir mendukung validitas isi tes \\
\hline 12 & 1 & 1 & 1 & 1 & Butir mendukung validitas isi tes \\
\hline 13 & 1 & 1 & 1 & 1 & Butir mendukung validitas isi tes \\
\hline 14 & 1 & 1 & 1 & 1 & Butir mendukung validitas isi tes \\
\hline 15 & 1 & 1 & 1 & 1 & Butir mendukung validitas isi tes \\
\hline
\end{tabular}

Berdasarkan tabel 1, menunjukkan bahwa dari 15 butir soal yang telaah dinilai oleh expert (validator) telah menunjukkan bahwa butir-butir tersebut mendukung validitas isi tes. Kemudian dari hasil CVR tersebut maka dihasilkan nilai CVI yang merupakan rata - rata dari CVR semua item sebesar 1. Sehingga berdasarkan kriteria CVI dari 15 butir soal tersebut termasuk kedalam kategori sangat sesuai.

\subsubsection{Analisis Angket siswa}

Hasil dari analisis angket respon siswa pada ujicoba one-to-one diperoleh ratarata respon positif siswa adalah $75 \%$ dan rata-rata respon negatif siswa adalah $25 \%$. Sedangkan pada ujicoba small group rata-rata respon positif siswa adalah 77,08\% dan rata-rata respon negatif siswa adalah 22,92\%. Dapat disimpulkan bahwa lebih dari $50 \%$ siswa yang memberikan respon positif., artinya keterbacaan soal sudah baik dan bisa dilanjutkan ke ujicoba field test.

\subsubsection{Uji Reliabilitas Instrumen Tes Kemampuan Pemecahan Masalah}

Berdasarkan hasil uji reliabilitas pada program SPSS versi 20 menunjukkan nilai reliabilitas instrumen tes pemecahan masalah matematika adalah 0,732 dengan intrpretasi tinggi. Hal ini menjukkan bahwa instrumrn dapat dikatakan reliabel

\subsubsection{Tingkat Kesukaran Instrumen Tes Kemampuan Pemecahan Masalah Matematika}

Tabel 2. Analisis Tingkat kesukaran Instrumen Tes Pemecahan Masalah Matematika

\begin{tabular}{ccc}
\hline No. Soal & Tingkat Kesukaran & Kategori \\
\hline 1 & 0,89 & Mudah \\
\hline 2 & 0,76 & Mudah \\
\hline 3 & 0,69 & Sedang \\
\hline 4 & 0,75 & Mudah \\
\hline 5 & 0,66 & Sedang \\
\hline 6 & 0,39 & Sedang \\
\hline 7 & 0,54 & Sedang \\
\hline 8 & 0,69 & Sedang \\
\hline 9 & 0,67 & Sedang \\
\hline 10 & 0,39 & Sedang \\
\hline 11 & 0,43 & Sedang \\
\hline
\end{tabular}




\begin{tabular}{ccc}
\hline 12 & 0,56 & Sedang \\
\hline 13 & 0,25 & Sukar \\
\hline 14 & 0,3 & Sukar \\
\hline 15 & 0,78 & Mudah \\
\hline Rata-rata & 0,58 & Sedang \\
\hline
\end{tabular}

Berdasarkan hasil analisis tingkat kesukaran pada tes kemampuan pemecahan masalah matematika, 4 butir soal memiliki tingkat kesukaran dengan kategori "mudah". 9 butir memiliki tingkat kesukaran dengan kategori "sedang" dan 2 butir soal memiliki tingkat kesukaran kategori "sukar". Rata-rata tingkat kesukaran yang diperoleh adalah 0,58 dengan kategori sedang, artinya tingkat kesukaran instrumen tes pemecahan masalah secara kesuluruhan cukup baik.

\subsubsection{Daya Pembeda Instrumen Tes Kemampuan Pemecahan Masalah Matematika}

Tabel 3. Analisis Daya Pembeda Instrumen Tes Pemecahan Masalah

Matematika

\begin{tabular}{ccc}
\hline No. Soal & Daya Pembeda & Kategori \\
\hline 1 & 0,26 & Cukup \\
\hline 2 & 0,56 & Baik \\
\hline 3 & 0,43 & Baik \\
\hline 4 & 0,35 & Cukup \\
\hline 5 & 0,35 & Cukup \\
\hline 6 & 0,38 & Cukup \\
\hline 7 & 0,55 & Baik \\
\hline 8 & 0,47 & Baik \\
\hline 9 & 0,2 & Jelek \\
\hline 10 & 0,21 & Cukup \\
\hline 11 & 0,37 & Cukup \\
\hline 12 & 0,25 & Cukup \\
\hline 13 & 0,36 & Cukup \\
\hline 14 & 0,29 & Cukup \\
\hline 15 & 0,21 & Cukup \\
\hline Rata-rata & 0,35 & Cukup \\
\hline
\end{tabular}

Berdasarkan hasil analisis daya pembeda instrumen tes pemecahan masalah matematika. Maka, diketahui bahwa 10 butir soal memiliki daya pemebeda dengan kategori "cukup". 4 butir soal memiliki daya pembeda dengan kategori "baik" dan terdapat satu butir soal yang memiliki daya pembeda yang jelek. Rata-rata daya pembeda pada soal pemecahan masalah matematika adalah 0,35 dengan kategori cukup artinya soal pemecahan masalah matematika mampu mebedakan kemampuan membedakan peserta tes yang berkemampuan tinggi dan berkemampuan rendah 


\subsubsection{Analisis Data Hasil Kemampuan Pemecahan Masalah Matematika}

Hasil analisis hasil tes kemampuan pemecahan masalah matematika siswa ditunjukkan sebagai berikut.

Tabel 4. Analisis Hasil Tes Kemampuan Pemecahan Masalah Matematika

\begin{tabular}{|c|c|c|c|}
\hline \multicolumn{4}{|c|}{ Siswa } \\
\hline Nilai Siswa & Frekuensi & Presentase $(\%)$ & Kategori \\
\hline $80-100$ & 2 & 5,56 & Sangat baik \\
\hline $60-79$ & 14 & 38,89 & Baik \\
\hline $40-59$ & 17 & 47,22 & Cukup \\
\hline $20-39$ & 3 & 8,33 & Kurang \\
\hline $0-19$ & 0 & 0 & Sangat kurang \\
\hline Jumlah Subjek & 36 & 100 & \\
\hline Rata-rata Nilai & & & Cukup \\
\hline
\end{tabular}

Berdasarkan analisis data untuk mengukur kemampuan pemecahan masalah matematika siswa diketahui dari 36 subjek uji coba terdapat 2 siswa $(5,56 \%)$ termasuk dalam kategori memiliki kemampuan pemecahan masalah matematika yang sangat baik, 14 siswa $(38,89 \%)$ termasuk dalam kategori memiliki kemampuan pemecahan masalah matematika yang baik, 17 siswa (47,22\%) termasuk kedalam kategori memiliki kemampuan pemecahan masalah matematika yang cukup, 3 siswa $(8,33 \%)$ termasuk dalam kategori memiliki kemampuan pemecahan masalah matematika yang kurang, dan tidak ada siswa yang termasuk kategori memiliki kemampuan pemecahan masalah matematika yang kurang.

\subsection{Pembahasan}

Pengembangan instrumen tes untuk mengukur kemampuan pemecahan masalah matematika siswa telah melalui serangkaian fase pengembangan model Tessmer mulai dari tahap preliminary, self evaluation, tahap prototyping (expert review, one-to-one, small goup) dan field test sehinga menghasilkan sebuah produk. Produk yang dimaksud adalah instrumen tes untuk mengukur pemecahan masalah matematika yang berjumlah 15 butir soal. Sebelum proses pengembangan dilakukan, telah ditetapkan suatu kriteria kualitas instrumen tes untuk melihat sejauh mana keberhasilan produk yang dihasilkan.

tahap preliminary merupakan tahap awal pada proses pengembangan, pada tahap ini, peneliti melakukan persiapan seperti mencari referensi berkaitan dengan peneltian 
yang akan dilakukan kemudian menentukan sekolah atau tempat meneniiti serta dan jadwal penelitian.

Tahap yang kedua adalah tahap self evaluation pada tahap ini terdiridari tahap analisis dan tahap desain. Pada tahap analisis terdiri dari tahap analisis siswa, analisi kurikulum dan analisis materi, setelah melakukan analisis peneliti lanjut ketahap desain. Pada tahap desain peneliti merancang instrumen tes pemecahan masalah matematika terdiri dari kisi-kisi, soal tes, kunci jawaban, dan pedoman penilaian. Rancangan ini disebut sebagai prototype I.

Tahap yang ketiga adalah tahap prototyping. Tahap ini terdiri dari expert review, one to one dan small group. Expert (validator) melakukan validasi terhadap instrumen tes pemecahan masalah matematika. Hasil validasi tersebut Selanjutnya dilanjutkan ke uji coba one to one. Hasil dari validator dan one to one selanjutnya digunakan untuk merevisi prototype I menjadi prototype II. Kemudian protoype II diujicobakan pada ujicoba small group. Hasil dari small group akan digunakan untuk mervisi jika ada revisi sehingga menjadi prototype III. Protoype III diujicobakan pada tahap akhir yaitu tahap field test, tahap field tes dilakukan pada kelas VIII-3 MTsN 1 Model makassar sebanyak 36 orang siswa. berdasarkan hasil pekerjaan siswa tersebut, maka reliabilitas, tingkat kesukaran dan daya pembeda instrumen tes dapat ditentukan.

Kualitas instrumen tes pemecahan masalah matematika dapat dilihat berdasrkan kriteri yang telah ditentukan. Hasil dari validasi tes memperoleh nilai CVR tiap butir soal yaitu 1 dan nilai CVI yaitu 1 artinya berdasarkan kriteria valid, apabila instrumen tes memilki $\mathrm{CVR} \geq 0,99$ dan $\mathrm{CVI} \geq 0,34$ maka instrumen tes pemecahan masalah matematika dinyatakan valid selanjutnya hasil dari one to one memenuhi keterbacaan soal. Rata-rata respon positif siswa adalah $75 \%$ dan rata-rata respon negatif siswa adalah 25\%. Pada tahap small group, Hasil dari angket respon yang diperoleh adalah rata-rata respon positif siswa adalah $77,08 \%$ dan rata-rata respon negatif siswa adalah $22,92 \%$. Berdasarkan kriteria maka hasil angket respon siswa memenuhi kriteria sesuai, artinya keterbacaan soal sudah bagus sehingga prototype II yang diperoleh dapa dilanjutkan ke tahap field test.

Berdasarkan hasil uji reliabilitas instrumen tes yang dilakukan pada program SPSS versi 20 diperoleh adalah 0,732 dengan interpretasi yang tinggi. Artinya instrumen tes pemecahan masalah dapat dikatakan reliabel atau dapat dipercaya untuk digunakan dalam mengukur kemampuan pemecahan masalah mateamatika siswa.

Tingkat kesukaran yang baik apabila tingkat kesukaran berada pada kisaran 0,31 - 0,70 dengan kategori sedang. Hasil analisis tingkat kesukaran dalam pengembangan instrumen tes kemampuan pemecahan masalah.26,67\% dari soal memiliki tingkat kesukaran dengan kategori mudah. 60\% dari soal tersebut memiliki tingkat kesukaran dengan kategori sedang. 13,33\% dari soal dengan kategori sukar, artinya instrumen tes yang dikembangkan memiliki kualitas cukup baik dengan melihat persentase dari soal dengan kategori sedang sebesar $60 \%$. Kemudian berdasarkan dari rata-rata tingkat kesukaran soal yaitu 0,58 dengan kategori sedang. Sehingga secara keseluruhan tingkat kesukaran instrumen tes pemecahan masalah sudah baik.

Daya pembeda instrumen tes berdasrkan kriteria soal yang baik terdapat pada rentang $0,20<\mathrm{Dp} \leq 1,0$. Berdasarkan hasil daya pembeda diatas maka, 26,67\% soal memiliki daya pembeda dengan kategori baik. $66,67 \%$ soal memiliki daya pembeda yang cukup dan $6,66 \%$ soal yang memiliki daya pembeda dengan kategori jelek. Daya pembeda yang sesuai kriteria yaitu daya pembeda dengan kategori cukup dan baik, hasil 
analisis tersebut menunjukkan 93,34\% dari soal sesuai dengan kriteria daya pembeda. Kemudian rata-rata daya pembeda yang diperoleh adalah 0,35 dengan kategori cukup berdasarkan hasil tersebut artinya instrumen tes yang dikembangkan cukup mampu membedakan siswa yang berkemampuan tinggi dan siswa yang berkemampuan rendah.

Berdasarkan hasil data tes untuk mengukur kemampuan pemecahan masalah matematika, dapat diketahui bahwa jumlah siswa yang termasuk dalam kategori memiliki tingkat kemampuan pemecahan masalah matematika sangat baik sebanyak 2 orang siswa $(5,56 \%)$. Jumlah siswa yang memiliki tingkat pemecahan masalah matematika kategori baik sebanyak 14 orang siswa $(38,89 \%)$. Jumlah siswa yang memiliki tingkat kemampuan pemecahan masalah matematika dengan kategori cukup baik sebanyak 17 orang siswa (47,22\%). Jumlah siswa yang memiliki tingkat kemapuan pemecahan masalah matematika dengan kategori kurang sebanyak 3 orang siswa $(8,33 \%)$.

Berdasarkan penjelasan diatas instrumen tes yang dikembangkan memenuhi kriteria valid dan reliabel kemudian jika dilihat dari tingkat kesukaran dan daya pembedanya. Ada soal yang memiliki tingkat kesukaran yang kurang baik namun secara kesulurahan instrumen tes memiliki tingkat kesukaran yang sesuai sehingga memenuhi kriteria tingkat kesukaran. Berdasarkan daya pembeda. Terdapat satu butir soal yang memiliki daya pembeda yang kurang baik, namun secara keseluruhan soal memiliki daya pembeda yang sesuai dengan kriteria. Oleh karena itu pengembangan istrumen tes untuk mengukur kemampuan pemecahan masalah mencapai prototype final.

\section{Kesimpulan}

Prosedur pengembangan dengan menggunakan model tessmer dilalui beberapa tahap yaitu tahap Preliminary, tahap formatif evaluation, tahap prototyping (expert review, one-to-one, small group), dan tahap fiel test. Kualitas instrumen tes telah memenuhi kriteria valid dan reliabel, serta tingkat kesukaran dan daya pembeda yang baik. Sehingga memenuhi kriteria tes yang baik.

\section{Daftar Pustaka}

Adek, P. (2014). Analisis Soal Ujian Nasional Matematika Smp/Mts Yang Didasarkan Pada Tingkat Pemahaman Konsep, Penalaran Dan Pemecahan Masalah; Skripsi, Universitas pendidikan indonesia.

Anggereni, S. (2014) Mengembangkan Asesmen Kinerja Melalui Pembelajaran Berbasis Laboratorium. Makassar: Alauddin University Press.

Arikunto, S. (2012). Dasar-Dasar Evaluasi Pendidikan. Jakarta: PT Bumi Aksara.

Hamzah, A. (2014). Evaluasi Pembelajaran Matematika. Jakarta: Rajawali Press.

Husna, Ikhsan, \& Fatimah. (2013). Peningkatan Kemampuan Pemecahan Masalah dan Komunikasi Matematis Siswa Sekolah Menengah Pertama Melalui Model Pemebelajaran Kooperatif Tipe Tink-Pair-Share (TPS). Jurnal Online Pendidikan Matematiak Unsiah Banda Aceh dan UPI Bandung, 1(2).

Imroatun, S. (2014). Strategi Pemecahan Masalah Matematika Siswa Kelas VII SMP Kristen 2 Salatiga ditinjau Dari Langkah Polya. Jurnal Online Program Studi Matematika Universitas Kristen Wacana. 
Lahinda, Y, \& Jailani. (2015). Analisis Proses Pemecahan Masalah Matematika Siswa Sekolah Menengah Pertama. Jurnal Online Pendidikan Matematiak Universitas Negeri Yogyakarta, 2(1).

Mania, S. (2014). Asesmen Autentik untuk Pembelajaran Aktif dan Kreatif Implementasi Kurikulum 2013. Makassar: Alauddin Universiy Press.

Mardapi, D. (2008). Teknik Penyusunan Instrumen Tes dan Nontes. Yogjakarta: Mitra Cendikia Press.

Mustami, K. (2015). Metodologi Penelitian Pendidikan. Yogyakarta: Aynat Publishing.

Nursalam. (2012). Pengukuran Dalam Pendidikan. Makassar: Alauddin University Press.

Purwanto. (2010). Instrumen Penelitian Sosial dan Pendidikan. Yogyakarta: Pustaka Belajar.

Orhun, N. (2003). Effect of Some Properties 5. Grade Student on the Perfomence of Mathematical Problem Solving. Jurnal Analdo University, Science Faculty, Depatement of Mathematics, Turkey, 6(1).

Rahayu, R., \& Kartono. (2014). The Effect of Mathematical Disposition toward Problem Solving Ability Based on IDEAL Problem Solver. Jurnal semarang State University, 3(10).

Silvia, Evita, Y., Zulkardi \& Darmawijoyo. (2011). Pengembangan Soal Matematika Model PISA Pada Konten Uncertainty untuk Mengukur Kemampuan Pemecahan Masalah Matematika Siswa Sekolah Menengah Pertama. Jurnal Online Pasca Sarjana Universitas Sriwijaya, 5(1).

Sudjana, N. (2008). Penilaian Hasil Proses Belajar Mengajar. Bandung: PT Remaja Rosda Karya.

Sugiman. Y.S., Kumah, \& Sabandar. (2009). Pemecahan Masalah Matematika Realistik. Jurnal Online Universitas Negeri Yogyakarta.

Sugiyono. (2014). Metode Penelitian Kuantitatif, Kulitatif dan R\&D. Bandung: Alfabeta.

Suryabrata, S. (2014). Metodologi Penelitian. Jakrata: Rajawali Press.

Syam, S., Rahman, U., Nursalam. (2016). Pengaruh Pengetahuan Metakognisi dan Gaya Belajar Visual Terhadap Kemampuan Pemecahan Masalah Matematika Siswa Kelas IX SMP Negeri 2 Barombong Kabupaten Gowa. MaPan : Jurnal Matematika dan Pembelajaran, 4 (2).

Taniredja, Tukiran, \& Mustafidah. (2011). Penelitian Kuantitatif Sebuah Pengantar. Bandung: Alfabeta. 